14 Anonymous. A British cholera mission. Br Med f 1884;ii:292.

15 Great Britain, India Office. Cholera: inquiry by doctors Klein and Gibbes, and transactions of a committee convened by the secretary of state for India in council. London: India Office. 1885.

${ }^{16}$ Sanderson JB. The cholera and the comma bacillus. $\mathrm{Br} \mathrm{Med} \mathcal{F} 1885$; : 1076-7.

17 Protocoles et procès-verbaux de la conférence sanitaire internationale inaugurée le 20 mai 1885. Rome: Imprimerie du Ministre des Affaires Etrangères, 1885

18 Pacini F. Osservazioni microscopiche e deduzioni patologiche sul cholera asiatico. Firenze: Bencini, 1854.

19 Judicial Commission, International Committee on Bacteriological Nomenclature. Opinion. International Bulletin Bacteriological Nomenclature $1965 ; 15: 185$.

\title{
Mother care for children in hospital
}

\author{
MICHAEL RYAN
}

Few measures of "throughput" in the Soviet health service can be obtained easily, and such published data as exist do not refer to the work of paediatric hospitals and departments. The only available measure of their activity is implied in a set of planning norms for major specialties that were to be implemented during the years 1980-5. For this period the Soviet Health Ministry envisaged a hospital admission rate of $24 \cdot 2 \%$ of the total population each year and, from the fact that the actual rate for 1981 stood at $24.0 \%$, it can be inferred that the norms are being observed.

So far as young patients are concerned the minimum level of hospital activity is suggested by figures for two categories specified in the Health Ministry's document of guidance. ${ }^{1}$ Thus there were to be 26.9 admissions per 1000 total population to "children's somatic" departments and 7.5 per 1000 to children's infectious disease beds. (Both targets represent an increase on the admissions recorded for 1970.) Unfortunately, the maximum planned level cannot be established without knowing what additional provision for the age group in question is concealed within the norms for certain other specialtiesfor example, psychiatry and tuberculosis.

Although these are incomplete and surrogate data, they at least point to a strategy that accords heavy (and increasing) emphasis to the treatment of children in hospital. Such a background lends added importance to a recent article conveying the varying responses of Soviet doctors to the question: Are mothers needed on the ward? The article comprises a review of correspondence received by Meditsinskaya Gazeta after its account of how the Penza regional children's hospital established a system whereby mothers could participate in the care of their own-and other people's-children. ${ }^{2}$

\section{For and against}

Most letters endorsed the initiative shown at the hospital in Penza, though, as will be shown later, concern for a child's psychological well being was not the sole consideration. Only one letter contained a statement of unequivocal opposition and that may be said fairly to bristle with prejudice. From three doctors at a children's department in Novorossisk came the

Centre of Russian and East European Studies, University College of Swansea, Swansea SA2 8PP

MICHAEL RYAN, PHD, lecturer in Soviet social policy condemnation: "This idea is not only illogical: it is harmful," and even: "what has been thought up in Penza is criminal." According to their perception, mothers in hospital are unauthorised persons who merely distract the staff with idle questions.

As for the trauma of separation from parents, these doctors show a totally dismissive attitude by asserting that: "A child gets accustomed to his new surroundings and becomes attached to the medical staff." In the same vein they comment: "without mothers, children are good as gold" (an obscurantist view also familiar to British pioneers in this subject). Whether justifiably or not they claim that mothers insist on taking children home before they are fit for discharge, and they make the recommendation (bizarre but consistent with their viewpoint) that "it is better to set up closed circuit television so that mothers can observe their children at fixed times."

One of the signatories of this letter was the head of department, who had worked as a paediatrician for 32 years. The next letter to be cited came from a doctor with a record of 50 years' service and is interesting for the light it casts on the progressive practice of an older generation-or more precisely of two revered clinicians, A A Kisel and N I Krasnogorski. Kisel was an advocate of the doctrine that "children are calmer when their parents are present, misbehave less, eat better and get to sleep more quickly in a bed made by mother's hands." Krasnogorski (born in 1882) had apparently pioneered the concept of "duty parents" and recognised the need to provide facilities within his clinic where parents could drink tea, rest, and relax.

Another correspondent identified a pragmatic consideration which, though logically unrelated to the emotional needs of young patients, points to the same conclusion. After paying tribute to the inventiveness and sensitivity of the Penza doctors he refers to misgivings expressed by several colleagues that the scheme could entail additional expenditure. Highlighting the broader implications, however, he notes that financial advantages would accrue if mothers perform the tasks of orderlies and if the children recuperate more rapidly in their presence. For the sake of clarity it should be added that an acute shortage of orderlies (sanitarki) is a management problem that most Soviet hospitals have had to cope with over many years.

Some readers raised questions that reflected concern about economic costs external to the health service. The point here is that mothers with jobs-the overwhelming majority of all Russian mothers-would generally require a sickness certificate to validate their absence from work. Possession of a sickness certificate, obviously enough, entitles the mother to social security payments, and they represent a financial burden on the state. 


\section{Concurrent treatment}

From the town of Namangan in the Uzbek republic came an interesting report of another new venture. In the regional children's hospital there, as its head doctor relates, mothers are admitted not only to help care for their youngsters but also to receive treatment themselves. This arrangement was made possible by the designation of a special "mother and child" department with a complement of 60 beds.

The rule is that all mothers attending this hospital with their children are examined by a general physician, and, if any symptoms come to light, mother and child receive medical care at the same time. This arrangement takes into account a key demographic feature of the area: in common with other parts of Soviet central Asia it has a high birth rate and an average family size that substantially exceeds the all Union figure. In the head doctor's opinion, "Women with five, six, or more children do not have the time to think about their own health." But once a mother comes to hospital on account of her child's illness, "she can and should be treated."

Among the practical difficulties that arose in Namangan was what action to take when a child had recovered before the mother's course of treatment was complete. For such an eventuality alternatives were devised; depending on her condition at the time a mother would either be transferred to the adult general medical department or be discharged and placed under the observation of her microdistrict (uchastok) doctor. A facility considered necessary but not yet in existence is a crèche offering round the clock care for children who no longer need nursing and medical attention.

\section{Legal position}

As the final section of its article, Meditsinskaya Gazeta printed a letter from one of the Soviet Union's deputy Health Ministers, Dr Ye Ch Novikova. Responsible for the organisation of maternity and child health services, she took the opportunity to restate official policy and encourage progressive tendencies. It emerges that the Ministry had sent a directive (when is not specified) to heads of health service organs and institutions requiring them "to strengthen control over the organisation of work in children's hospitals and to enlist the help of mothers more widely in the care of sick children."

As for the logistic consequences of this policy, Dr Novikova states that the physical conditions necessary for the mothers' stay are being created: "In contemporary plans for children's hospitals, special accommodation is envisaged for them-where they can sleep, eat, and so on." At existing hospitals appropriate provision can be made when reconstruction occurs.

In an important qualification, though, the deputy Minister foresees a continuance of the status quo at many units. Even today, she admits, many children's hospitals (including some in Moscow) suffer from overcrowding and so cannot set aside additional space for mothers. In these units, apparently, only when an infant is under 1 year may the mother stay with him, and even then-the text here is quite unambiguous - the mothers of such children must leave at night.

As it happens, the age limit referred to has a basis in law. Indeed Dr Novikova herself goes on to note that article 42 of the Principles of Health Service Legislation (passed in 1969) states that during inpatient treatment of a child less than 1 year old, and also of a gravely ill older child needing constant attention, a mother will be given the opportunity to remain with her child. In such instances a sickness certificate is issued to cover the period during which she has to remain in hospital.

\section{Conclusion}

To judge from what was said about overcrowded hospitals, the legislators' intention continues to be disregarded in many places if by "remain with her child" is meant close proximity at night as well as during the day. On a positive note, however, the correspondence conveys the impression that a not insignificant body of Soviet medical opinion has now advanced well beyond the minimalist position enshrined in the 1969 legislation. Perhaps the care of children is pre-eminently a field in which natural sentiment combines with the dictates of psychology and economics to induce agreement with Edmund Burke's wise dictum: "We must all obey the great law of change."

\section{References}

${ }^{1}$ Safonov AG, Loginova EA, redaktori. Osnovi organizatsii statsionarnoi pomoshchi $v$ SSSR. Moskva: Meditsina, 1976:105.

${ }^{2}$ Reznyuk G. Nuzhna li mama v bolnitse ? Meditsinskaya Gazeta 1983 Jan $14: 2$.

(Accepted 11 November 1983)
Traditional folk treatments practised in the Third World may give rise to signs and symptoms suggestive of non-accidental injury. The recent arrival of refugees from Vietnam has brought these problems to light.

A 9 year old girl, born in a Hong Kong transit camp to North Vietnamese parents, arrived in Glasgow with her parents in September 1981. Vietnamese children are susceptible to upper respiratory tract infections in Britain, ${ }^{1}$ and during the first six months of residence this child was seen by one of us (AGJ) because of five upper respiratory tract infections. She presented with a mild bronchitis and was prescribed an antibiotic and an expectorant. At this time she was noted to have faint bruises on her lower back. She was reviewed four days later, at which time there were two fresh, livid, linear bruises on her posterior chest and four similar marks on her neck. The chest infection settled in five days, and the bruises had faded completely by the fourth day.

Non-accidental injury was suspected in this child because of the association between unexplained linear bruising and multiple upper respiratory infections. A case conference was convened, and with the help of an interpreter the true facts emerged. The bruising had been produced by a form of "paediatric massage" known as " $t$ ' $i$-sha," "chih-sha," "nieh-sha," or "nui-sha." 2 In these techniques the skin is "pinched and pulled" between the curved index and middle fingers.
The effectiveness of the technique may be accentuated by prior rubbing of aromatic substances or alcohol on to the part to be massaged $^{2}$ (this family used whisky). The "massage" is continued until bruising appears. Many areas of the body may be chosen for massage but the most common are the posterior back (for chest infections), the neck (for sore throats), and the area between the eyebrows (for sinusitis or headaches). The linear nature of the bruising may suggest violent non-accidental injury such as beating with a stick or a belt. The Vietnamese practice of rubbing irritants on to the skin has been reported before ${ }^{3}$ but no comment was made on the amount of force required to produce the desired result. In this family there was no animosity between parents and child, indeed the father proudly displayed similar lesions on his own neck. We believe, however, that the deliberate production of bruises on small children must be regarded as an unnecessary practice that should be deterred in the United Kingdom. -N B SIMPSON, consultant, A G JAMIESON, principal, and H S GOH, student, Glasgow.

\footnotetext{
Phillips SJ, Pearson RJ. Dealing with Vietnamese refugees. Br Med $f 1981 ; 282$.

613-6.
2 S Department of Health, Education, and Welfare. A barefoot doctor's manual (translation of a Chinese instruction to certain Chinese health personnel) Bethesda, Maryland: Public Health Service National Institutes of Health, 1974 : $79-83$.

Coffman DA. Camera in general practice. Update 1983;26:5.
} 